\title{
ANTIMICROBIAL ACTIVITY OF HYMENAEA COURBARIL L. FRUIT
}

\author{
MARIANA NARVAEZ CORREA ${ }^{1}$, OSCAR EDUARDO RODRÍGUEZ AGUIRRE², \\ JANETH DEL CARMEN ARIAS PALACIOS ${ }^{1 *}$
}

\begin{abstract}
${ }^{1}$ Department of Microbiology, Industrial and Environmental Biotechnology Microbiology Group, Pontificia Universidad Javeriana, Bogotá, Colombia. ${ }^{2}$ Environmental Engineering Program, Faculty of Engineering, Universidad El Bosque, Research Group CHOC-IZONE, Bogotá, Colombia. Email: jdcarias@javeriana.edu.co
\end{abstract}

Received: 26 February 2020, Revised and Accepted: 31 March 2020

\section{ABSTRACT}

Objective: The assessment of the antimicrobial activity of Hymenaea courbaril L. on different microorganisms was realized with four bacteria, Escherichia coli, Staphylococcus aureus, Bacillus subtilis, and Pseudomonas aeruginosa, two yeasts Candida albicans and Saccharomyces cerevisiae, and finally two filamentous fungi Aspergillus niger.

Methods: The method of plates and wells was used, using extracts from the fruit of the plant mentioned above. These extracts were made with different solvents such as hexane, dichloromethane, ethanol, and aqueous.

Results: It was determined that the dichloromethane extract of $H$. courbaril L. has antimicrobial activity against the bacterium $S$. aureus showing a percentage of inhibition of $1.47 \%$.

Conclusions: In comparison to bacteria, fungi do not represent a significant inhibitory capacity which represents that when comparing these extracts of this plant, under the test conditions evaluated, it was presented that they obtained antimicrobial activity against $S$. aureus.

Keywords: Antimicrobial activity, Hymenaea courbaril L., Bacteria, Fungi, Extract, Solvents, Staphylococcus aureus.

(c) 2020 The Authors. Published by Innovare Academic Sciences Pvt Ltd. This is an open access article under the CC BY license (http://creativecommons. org/licenses/by/4. 0/) DOI: http://dx.doi.org/10.22159/ajpcr.2020.v13i6.37272

\section{INTRODUCTION}

The traditional system of herbal medicine has become a topic of global importance since they are considered as rich sources of lead compounds and quietly safe for both human use and environment friendly [1]. Plants have played a fundamental role in the life of man who has used them to meet basic needs such as food, medicine, shelter, and clothing, even in ritual acts. The use of plants is a practice that exists since the beginning of the human species [2]. On the other hand, plants have been able to develop different strategies to defend against pathogenic microorganisms, such as the production of secondary metabolites with antimicrobial activity. Some secondary metabolites are terpenes, phenols, flavonoids, quinines, tannins, and alkaloids, which are used for the production of phytomedicines due to its antimicrobial properties. These are products made with the purpose of treating different diseases where one of the main ingredients may be extracts of plant origin [2]. World plant biodiversity is the largest source of herbal medicine, and still, about $60-80 \%$ world population rely on plant-based medicines which are being used since the ancient ages as traditional health-care system [3].

\section{METHODS}

Obtaining strains of bacteria such as Escherichia coli (CMPUJ: 034), Staphylococcus aureus (CMPUJ: 370), Bacillus subtilis, and Pseudomonas aeruginosa (CMPUJ: 065) and fungi such as Candida albicans (CMPUJ: H0 22), Saccharomyces cerevisiae (CMPUJ: H042), Penicillium chrysogenum (CMPUJ: H061), and Aspergillus niger (CMPUJ: H002) provided by Pontifical Javeriana University bacteria and fungi microorganism collection.

\section{Preparation of extracts}

According to the method described by Dah-Nouvlessounon et al. [4,5], the extraction process was carried out with the fruit of the plant separately, using Soxhlet extraction and using as solvents hexane, dichloromethane, ethanol, and aqueous. These extracts were solubilized and brought to a final concentration of $100 \mathrm{mg} / \mathrm{mL}$ in dimethyl sulfoxide (DMSO) for later use.

\section{Preparation of inoculums}

This method starts with preparation of the microorganisms' suspension for test and validation, from a bacterial suspension where values are giving in a number of colonies forming units (CFU) $1.5 \times 10^{8} \mathrm{CFU} / \mathrm{ml}$. From microorganisms sown in TSA and PDA for bacteria and fungi, respectively, isolated colonies were taken with a sterile handle and subsequently added to a sterile peptide water tube, where it serves for the recovery of microorganisms, to obtain a turbidity and $10^{8}$ cells $/ \mathrm{mL}$ on the McFarland scale. The media used were TSA for Bacterias and PDA for fungi. For the TSA preparation, $10.56 \mathrm{~g}$ of commercial TSA was prepared and added to a Schott bottle with $264 \mathrm{~mL}$ of distilled water under stirring and constant temperature. Subsequently, the medium was completely homogenized with the water and the medium was sterilized in an autoclave at a temperature of $121^{\circ} \mathrm{C}$. For the preparation of PDA used for the cultivation of fungi and yeasts, $24.38 \mathrm{~g}$ of commercial PDA was seized and added to a Schott bottle with $264 \mathrm{~mL}$ of distilled water under stirring and constant temperature. It shakes up homogen medium with water and sterilized the autoclave medium at $121^{\circ} \mathrm{C}$.

\section{Preparation of controls}

DMSO was used as a negative control in each microorganism and a commercial antifungal (surgical) for bacteria and fungi was used as a positive control. A volume of $30 \mu \mathrm{l}$ was used in each control.

\section{Preparation and identification of Petri boxes}

From the inocules made, an aliquot of $50 \mathrm{~mL}$ was taken and added to $500 \mathrm{~mL}$ of TSA and sterile molten PDA. Subsequently, approximately $22 \mathrm{~mL}$ of inoculated medium was added to Petri boxes with the strain of each microorganism and the agar layer was solidified. 
When the medium solidified, 6 holes were performed on the agar (Fig. 1), from the agar surface to the base of the box with the help of an inverted pipette. Finally, extracts were added in 4 wells in different volumes $(10 \mu \mathrm{l}, 20 \mu \mathrm{l}, 30 \mu \mathrm{l}$, and $50 \mu \mathrm{l})$ and in 2 wells which are both positive and negative controls, $30 \mu \mathrm{l}$ of Quirucidal and DMSO were added, respectively.

\section{Reading and analyzing results}

Finishing the incubation time was performed the reading of the inhibition halos obtained in each well, subtracting the diameter of the well. Inhibition halos were expressed in centimeters $(\mathrm{cm})$ and antimicrobial activity was determined as a relative inhibition percentage (RPI) using the following formula [6]:

$$
R P I=\frac{D_{i}-D_{n}}{D_{p}-D_{n}} \times 100
$$

Where, $D_{i}$ is the diameter of the zone of inhibition of the extract, $D_{n}$ is the zone of inhibition diameter of the negative control, and $D_{p}$ is the diameter of the zone of inhibition of the positive control, where DMS and Quirucidal were used as antifungal, respectively.

\section{Statistical model}

Taking into account that fractions independent samples are available, the test is applied to contrast the effect of the fraction and the volume on the observed variable inhibition percentage: $\mathrm{y}_{\mathrm{ij}}$

$$
\mathrm{y}_{\mathrm{ij}}=\mu+\tau_{\mathrm{i}}+\theta_{\mathrm{j}}+\tau \theta_{\mathrm{ij}}+\varepsilon_{\mathrm{ij}}
$$

Where,

$\tau:$ Effect of the type of the fraction

$\theta_{i}$ : Effect of the volume

$\mu$ : Medium

$\tau \theta_{\mathrm{ij}}$ : Effect produced by the interaction between the fraction and the volume

$\varepsilon_{\mathrm{ij}}$ : Random error

The levels of the fractions are: $i=1=$ hexane; $i=2=$ Dichloromethane3 -Aqueous volume factor levels are: $j=1=10 \mathrm{uL} ; j=2=0 \mathrm{uL} ; j=3=30 \mathrm{uL}$; $\mathrm{j}=4=50 \mathrm{uL}$

\section{Testing on fractions}

In this case, it was tested if there are significant differences in the percentage of inhibition over the bacteria by the type of fraction, then the hypotheses are

$\mathrm{H}_{0}$ : The answer (inhibition) is the same about the bacteria S. aureus in each of the fractions. $\mathrm{H}_{1}$ : At least one response (inhibition) is significantly different about $S$. aureus bacteria due to the extract

$$
\mathrm{E}_{0}: \mu_{\mathrm{y}_{\mathrm{ij}}}=\mu_{\mathrm{y}} \quad \mathrm{j}
$$

In other words, we want to verify if there are significant differences on the inhibition response by the effect of the fraction.

To perform this test, it must first be verified that the percentage inhibition variable meets the conditions of the variance analysis.

\section{Normality test}

This test contrasts the observed variable with the quartiles of the normal distribution. Within the different tests, the Shapiro-Wilk test was applied, which with $p<0.05$ (significance value) rejects the null hypothesis which means that the variable has significant differences with the quants of the normal distribution.

\section{Equality of variances}

Test considering that it was not significant for normality, and then, a test of equal variances called homoscedasticity was performed, using the Levene test.

$$
\mathrm{H}_{1}: \mu_{\mathrm{y}_{\mathrm{ij}}} \neq \mu_{\mathrm{y}} \mathrm{K}_{\mathrm{j}}
$$

The result of the test shows that it is significant for equal variances for the two populations of microorganisms, because $p$ value in both cases is $<0.05$.

\section{RESULTS}

The results revealed that the extract of Hymenaea courbaril L. fruit in the hexane, dichloromethane, and aqueous fraction showed antibacterial activity. The antimicrobial activity of fruit extracts from $H$. courbaril $\mathrm{L}$. plant was assessed using the plaques and wells method, on different microorganisms: The bacteria used were E. coli, S. aureus, B. subtilis, and P. aeruginosa; filamentous mushrooms such as $P$. chrysogenum and $A$. niger; and for yeast $S$. cerevisiae and C. albicans. Variation factors in the inhibition response were related to the solvents used and the different volumes of $10 \mu \mathrm{L}, 20 \mu \mathrm{L}, 30 \mu \mathrm{L}$ and $50 \mu \mathrm{L}$.

As for negative control, there was no antimicrobial activity against the microorganisms studied, while positive controls exhibited antimicrobial activity, which varied depending on the microorganism. Therefore, for each experiment, the inhibition percentage was calculated.

As shown in Table 1, the extract of $H$. courbaril L. fruit in the hexane, dichloromethane, and aqueous fraction showed antibacterial activity. The fraction in dichloromethane is the one that has the best activity for the microorganism S. aureus; also, the hexane fraction recorded a percentage activity of 0 , while dichloromethane has activity in $90 \%$ of cases

For the case of the microorganism B. subtilis, the greatest activity is in aqueous. On the other hand, $S$. aureus is the bacterium that exhibited the most sensitivity to all the different extracts (Figs. 2 and 3). On the other hand, no inhibition zone was recorded over the bacteria $E$. coli and $P$. aeruginosa, which means their resistance to the different ones in the extracts.

For B. subtilis case, the aqueous fraction had a higher potential antibacterial activity without $\%$ zero inhibition for the unlike hexane, Figs. 4 and 5.

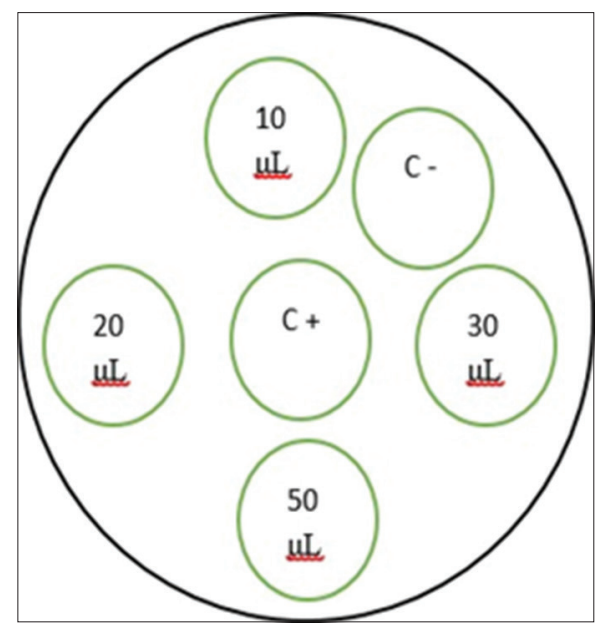

Fig. 1: Petri box preparation scheme for microbiological power determination from the plate and well method. A positive control $(\mathrm{C}+)$, a negative control ( $\mathrm{C}-$ ), and different volumes of the extract are used 
In addition, it was observed that there was no antifungal activity on the whole of fungi. They did not present a sensitivity to the extracts presented in this study. In addition, antimicrobial activity on fungi is not shown, where no extract is observed to exhibit inhibition against fungi and yeasts used.

\section{DISCUSSION}

The bacteria E. coli and P. aeruginosa did not register any inhibition zone, this could occur because they are Gram-negative bacteria and the composition of their cell wall, this natural resistance, is mainly due to the presence of an unpermeable outer membrane. According to a study by Fernandez et al., 2005 [7], H. courbaril L. inhibited 36.6\% of all Gram-positive isolations, including S. aureus and a percentage of inhibition was not observed with respect to Gram-negative bacteria. Both at present studied and in the research of Fernandez et al., reduced antimicrobial activity was shown in the four extracts in Gram-negative bacteria, one of the reasons why an inhibitory effect could be evident is because there were various chemical components in plants that can inhibit certain microorganisms, such as flavonoids and tannins. As for flavonoids, they are substances widely distributed in nature and contribute to the coloration of flowers, fruits, and leaves. Different studies describe anti-inflammatory and antioxidant activity in flavonoids. Likewise, authors describe phenols and flavonoids as the most widely found secondary metabolites found in plants. Secondary metabolites present in plants. Phenols are aromatic compounds which contain one or several hydroxyl groups directly attached to the benzene ring. Phenolic compounds exhibit antioxidant, antimutagenic, and anticancer activities $[8,9]$

Among flavonoids are the quercetin that has a higher antibacterial activity $[10,11]$ significantly inhibiting E. coli and P. aeruginosa, although there is a stronger bacteriostatic effect against the bacteria $S$. aureus, due to differences than differences than differences that presented with Gram-negative bacteria in cell wall and membrane structure and

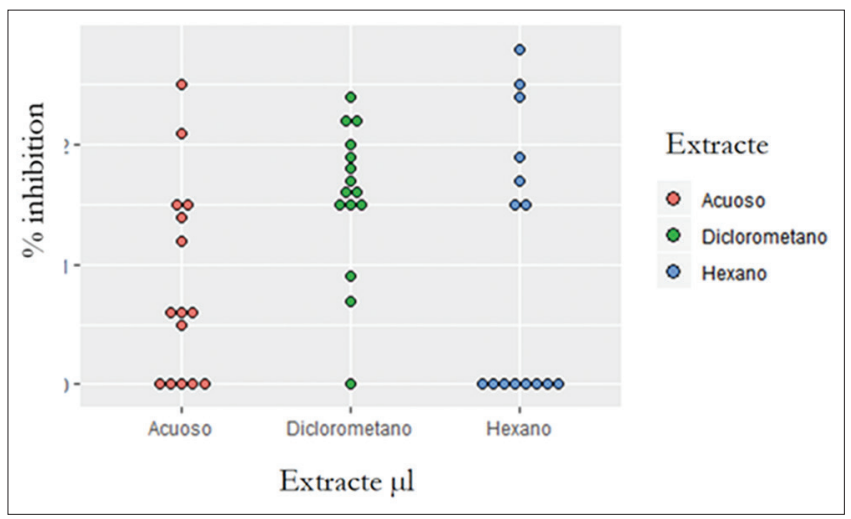

Fig. 2: Inhibition activity on Staphylococcus aureus

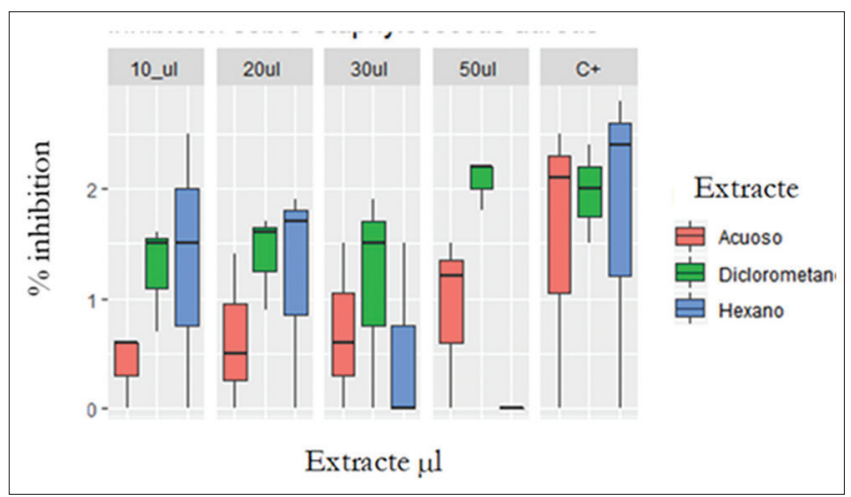

Fig. 3: Inhibition of Staphylococcus aureus against the most efficient extracts with the respective volume used composition, this compares with the results present in this study since none of the Gram-negative bacteria exhibited inhibition halos. S. aureus is the microorganism who had the highest percentage of inhibition with dichloromethane extract, as shown in Fig. 3 [12].

All the used solvents do not have the same extraction capacity because the yields vary according to the solvents. The variability of yields could be explained by the ability of extracting of each solvent which depends first on the solvent affinity with the phytomolecules and, on the other hand, the polarity of the solvent. For the four solvents used with $H$. courbaril L. fruit extract against $C$. albicans and $S$. cerevisiae yeasts, unlike bacteria these yeasts exhibited no antimicrobial activity, showing no antimicrobial activity, showing no inhibition halos only in positive controls with commercial Quirucidal, the same result was evident in the filamentous fungi $P$. chrysogenum and A. niger. Although the cell wall of filamentous fungi is composed of glucan (30-80\%), chitin and chitosan (1-15\%), manane, and glycoproteins, similar to the composition of the cell wall of yeasts differing in the amounts of each compound, specifically in chitin [13]. Where chitin allows greater resistance to antifungals because it increases when the cell wall is being affected by some compound, with the above mentioned, it can be said that when the cell has high levels of chitin which is less susceptible to an antifungal and this is reflected in this study where fungi and yeasts had no sensitivity or percentage of inhibition in the solvents evaluated [8].

In a study by Tamayo et al. [14,15], the ethanolic extract demonstrated antifungal activity against a plant pathogen Pestalo tiasubculturalis, at a concentration of $3.0 \mathrm{mg} / \mathrm{ml}$. This ethanolic extract and resin have demonstrated antimicrobial activity against B. subtilis, E. coli, $P$. aeruginosa, S. aureus, A. niger, and C. albicans. On the other hand, it has been documented that it has activity against a wide range of yeasts

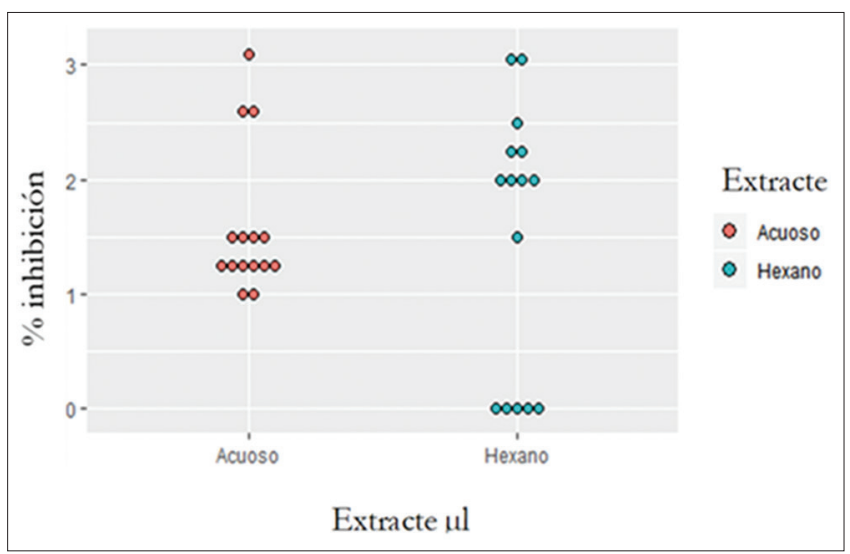

Fig. 4: Bacillus subtilis inhibition activity

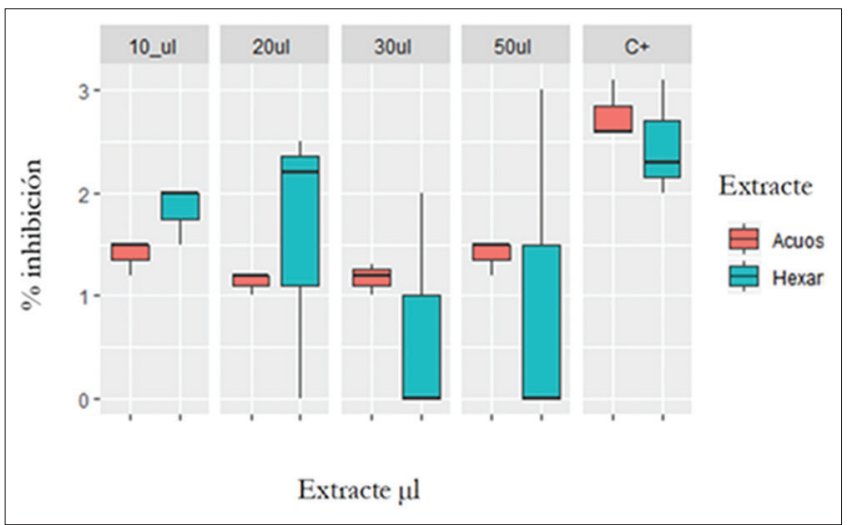

Fig. 5: Inhibition of Bacillus subtilis against the two most efficient extracts with the respective volume used 
Table 1: Percentage of average inhibition of extracts that exhibited antibacterial activity of the fruit of Hymenaea courbaril L.

\begin{tabular}{llll}
\hline Microorganism & Extract & $\begin{array}{l}\text { \% inhibitión } \\
\text { media }\end{array}$ & $\begin{array}{l}\text { \% } \\
\text { inhibition } \\
\text { variance }\end{array}$ \\
\hline \multirow{5}{*}{ Staphylococcus aureus } & Hexano & 0.76 & 0.97 \\
& Control + & 0.76 & \\
& Diclorometano & 1.47 & 0.64 \\
& Control + & 1.97 & \\
& Acuoso & 0.66 & 0.61 \\
& Control + & 1.53 & \\
Bacillus subtilis & Acuoso & 1.28 & 0.19 \\
& Control + & 2.77 & \\
& Hexano & 1.27 & 1.17 \\
& Control + & 1.27 & \\
\hline
\end{tabular}

including Candida. Other clinical studies that have been developed have shown that it has antimicrobial properties and antibacterial activities, including in vitro actions against organisms such as E. coli, Pseudomonas, Staphylococcus, and Bacillus. In addition, an aqueous extract of the leaves of this plant has demonstrated significant hypoglycemic activity, producing a significant reduction in blood sugar levels $[16,17]$.

\section{CONCLUSIONS}

Dichloromethane and aqueous extract used had the highest antibacterial activity, respectively, in the experiments conducted against Gram-positive bacteria $S$. aureus and B. subtilis, promise as a potential source of pharmaceutically important phytochemicals. The antimicrobial activity of $H$. courbaril L. fruit was evaluated against bacteria and fungi where quite a few cases have been reported in the pathologies presented in humans and this plant was shown to have the ability to significantly inhibit in terms of extracts. As for the fungi used in this study, they did not present any percentage of inhibition against the extracts used, due to their cell wall or the low concentrations of the compounds.

\section{ACKNOWLEDGMENT/FUNDINGS}

The authors are thankful to Javeriana University and Labfarve laboratories for support this research.

\section{AUTHORS' CONTRIBUTIONS}

All authors had equally contributed the research work.

\section{CONFLICTS OF INTEREST}

All authors have none to declare.

\section{REFERENCES}

1. Pradeepa M, Kalidas V, Geetha N. Qualitative and quantitative phytochemical analysis and bactericidal activity of Pelargonium graveolens lâ€TMher. Int J Appl Pharm 2016;8:7-11.

2. Celis A, Mendoza C, Pachón M, Cardona J, Delgado W, Cuca L. Extractos vegetales utilizados como biocontroladores con énfasis en la familia piperaceae. Una revisión. Agron Colomb 2008;26:97-106.

3. Sepúlveda JG, Porta DH, Rocha SM. La Participación de los Metabolitos Secundarios en la Defensa de las Plantas. Rev Mex Fitopatol 2003;21:355-63.

4. Nounagnon MS, Dah-nouvlessounon D, Ntcha C, Legba F, Babamoussa A, Adjanohoun A, et al. Phytochemistry and biological activities of Crateva adansonii extracts. Int J Pharm Pharm Sci 2018;10:62-7.

5. Nouvlessounon DD, Adoukonou SH, Diarrassouba N, Sina H, Adjonohoun A, Inoussa M, et al. Phytochemical analysis and biological activities of Cola nitida Bark. Biochem Res Int 2015;2015:493879.

6. Banothu V, Adepally U, Lingam J. In vitro total phenolics, flavonoids contents, antioxidant and antimicrobial activites of various solvent extracts from the medicinal plant Physalis minima Linn. Int J Pharm Pharm Sci 2017;9:192-8

7. Chhetri HP, Yogol NS, Sherchan J, Anupa KC, Mansoor S, Thapa P. Formulation and evaluation of antimicrobial herbal ointment. Kathmandu Univ J Sci Eng Technol 2010;6:102-7.

8. Fernandes T, Teixeira A, Pimenta F. Atividade antimicrobiana das plantas. Plathymenia reticulata, Hymenaea courbaril E Guazuma ulmifolia. Rev Patol Trop 2005;34:113-22.

9. Santos JA, Matos RA, Andrade EM, Santos WN, Magalhães HI, Costa FN, et al. Multielement determination of macro and micro contents in medicinal plants and phytomedicines from Brazil by ICP OES. J Braz Chem Soc 2017;28:376-84.

10. Khajapeer KV, Biswal R, Baskaran R. Evaluation of anti-cml activity of methanol and aqueous extracts of Benkara malabarica (Lam.) tirveng plant leaves. Int J Pharm Pharm Sci 2018;10:112-8.

11. Marinova D, Ribarova F, Atanassova M. Total phenolics and total flavonoids in Bulgarian fruits and vegetables. J Chem Technol Metall 2005;40:255-60.

12. Katalinic V, Milos M, Kulisic T, Jukic M. Screening of 70 medicinal plant extracts for antioxidant capacity and total phenols. Food Chem 2006;94:550-7.

13. Amoa OP, Ntie-Kang F, Lifongo L, Ndom J, Sippl W, Mbaze L. The potential of anti-malarial compounds derived from African medicinal plants, Part I: A pharmacological evaluation of alkaloids and terpenoids. Malar J 2013;12:449-74.

14. Tamayo LM, Arteaga DM, Jaramillo Y. Propiedades farmacológicas del Algarrobo (Hymenaea courbaril Linneaus) de interés para la industria de alimentos. Rev Lasallista Invest 2008;5:100-11.

15. Gomes CH, Rocha SF, Fonseca C, Assirati L. Determinacao in vitro da atividade antibacteriana dos extractos brutos da casca e polpa farinácea de Hymenaea courbaril L. Investigação 2010;10 37-43.

16. Aranda MA, Lopez MF, Lopez-Llorca LV. Cell wall composition plays a key role on sensitivity of filamentous fungi to chitosan. J Basic Microbiol 2016;56:1059-70.

17. Luo Y, Wang J, Liu B, Wang Z, Yuan Y, Yue T. Effect of yeast cell morphology, cell wall physical structure and chemical composition on patulin adsorption. PLoS One 2015;10:e0136045. 